\title{
Improving assent in health research: a rapid systematic review
}

\author{
Dominik Soll ${ }^{*}$ (D), Maria Magdalena Guraiib², Nigel Campbell Rollins ${ }^{3}$ and Andreas Alois Reis ${ }^{2}$
}

\begin{abstract}
Background: Enrolment in a research study requires the participant's informed consent. In the case of minors, informed consent of the respective legal guardian is obtained in conjunction with informed assent of the underage $\mathrm{p}$

articipant. Since comprehension of the information provided may be limited, effective interventions to improve understanding should be identified. Thus, it is the objective of this study to review quantitative studies that tested interventions to improve the understanding of information provided during assent processes in health research. The studied population consisted of minors that participated or were willing to participate in research. The primary outcome was the level of comprehension after intervention.
\end{abstract}

Methods: A systematic search was conducted in eleven databases including regional databases: PubMed, Web of Science, ERIC, PsycINFO, CINAHL, POPLINE, AIM, LILACS, WPRIM, IMSEAR, and IMEMR and included references from inception of the database until July 2018 except PubMed which spanned the period from May 2013 to July 2018. Search terms focused on Informed Consent/Assent, Minors, and Comprehension. To complement the search, reference lists of retrieved publications were additionally searched. We included all quantitative studies that were conducted in minors, tested an intervention, covered assent processes in health research, and assessed comprehension. One reviewer screened titles, abstracts, and full-texts to determine eligibility and collected data on study design, population, intervention, methods, outcome, and for critical appraisal. Interventions comprised enhanced paper forms, interspersed questions, multimedia format, and others.

Results: Out of 7089 studies initially identified, 19 studies comprising 2805 participants and conducted in seven countries were included in the review. Fourteen studies (74 \%) tested an intervention against control and ten (53 $\%$ ) were randomized controlled trials. Heterogeneous methodology as well as incomplete outcome and statistical reporting impaired the reliability of the collected data. Positive effects were suggested for use of enhanced paper forms, interspersed questions, use of pie charts, and organizational factors.

Conclusions: Improving assent in health research is an under-researched area with little reliable evidence. While some interventions are proposed to improve understanding in assent processes, further investigation is necessary to be able to give evidence-based recommendations.

Trial registration: PROSPERO ID: 106808.

Keywords: Informed consent, informed assent, informed consent forms, minors, adolescents, children, comprehension, understanding, rapid review

\footnotetext{
* Correspondence: dominik.soll@charite.de

'Department of Endocrinology and Metabolism, Charité Universitätsmedizin Berlin, Berlin, Germany

Full list of author information is available at the end of the article
}

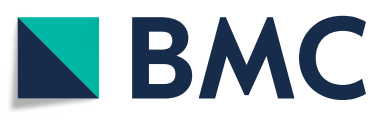

(c) The Author(s). 2020 Open Access This article is licensed under a Creative Commons Attribution 4.0 International License, which permits use, sharing, adaptation, distribution and reproduction in any medium or format, as long as you give appropriate credit to the original author(s) and the source, provide a link to the Creative Commons licence, and indicate if changes were made. The images or other third party material in this article are included in the article's Creative Commons licence, unless indicated otherwise in a credit line to the material. If material is not included in the article's Creative Commons licence and your intended use is not permitted by statutory regulation or exceeds the permitted use, you will need to obtain permission directly from the copyright holder. To view a copy of this licence, visit http://creativecommons.org/licenses/by/4.0/ The Creative Commons Public Domain Dedication waiver (http://creativecommons.org/publicdomain/zero/1.0/) applies to the data made available in this article, unless otherwise stated in a credit line to the data. 


\section{Background}

Out of 26917 clinical trials that have been registered on ClinicalTrials.gov in 2019, more than 4700 included individuals under the age of 18 years [1]. Similar to adults, adolescents and children have a right and interest to participate in health research to ultimately benefit from its outcome. Since minors may have difficulties balancing risks and benefits, they are considered a vulnerable population. Thus, special requirements have to be met to include them in research.

Based on the principle of respect for persons, involvement in a study requires the participant's informed consent [2]. In the case of minors, obtaining informed consent of the respective legal guardian in conjunction with informed assent of the underage participant is required. Usually, the minor's decision prevails. The Council for International Organizations of Medical Sciences (CIOMS) provides guidelines regarding the consent/ assent process in matters of content and comprehension. Among other things, the information should cover the study's aims, procedures, anticipated benefits and potential risks as well as the voluntariness of participation and the right to withdraw at any times [2]. It is also essential, however, to ensure that the potential participant sufficiently understands the information provided.

One report demonstrated that the comprehension of study details by minors often is unsatisfactory with about $50 \%$ not remembering that their treatment was considered research a few months after enrolment in the studies [3]. Although there are publications that provide guidance in assent processes, the recommendations often lack evidence [4]. However, different and novel ways of communicating information to minors have lately been under investigation.

This review summarizes published data from quantitative studies examining assent processes to identify interventions that promote the highest level of understanding among minors in health research of the information provided. Thus, it is the aim of this paper to provide guidance to future researchers on how to develop more effective assent processes.

\section{Methods}

This rapid systematic review was registered in PROSPERO 2018 (ID: 106808) and follows the Preferred Reporting Items for Systematic Reviews and MetaAnalyses (PRISMA) statement (Fig. S1).

\section{Eligibility criteria}

We included studies that evaluated factors and interventions in assent processes for minors in health research in regard of their impact on understanding. However, studies were excluded if 1$)$ the study did not include children or adolescents (< 18 years); 2) the tested assent form was not for health research; 3) no intervention was tested; 4) the produced data was purely qualitative or narrative or 5) comprehension was not tested. There were no restrictions in respect of language.

\section{Search strategy}

The literature search was conducted in eleven databases: PubMed, Web of Science, ERIC, PsycINFO, CINAHL, POPLINE, AIM, LILACS, WPRIM, IMSEAR, and IMEMR.

The search strategies were designed with input from an expert librarian to cover publications about Informed Consent/Assent, Minors, and Comprehension (Table S1). The searches were conducted between 26/07/2018 and 03/08/2018. Since a prior review covered earlier publications, the search in PubMed was restricted to papers published since May 2013 [5]. For other databases, the search was not limited in time. Additional records were identified by perusing references of retrieved publications.

\section{Assessment of studies}

One reviewer screened all titles and/or abstracts and assessed full-texts to determine eligibility. If no full-text was available, authors were contacted to gain access. In case of queries about the potential eligibility of a study, these were discussed with at least one of the other reviewers and a joint solution was found.

\section{Data collection, synthesis and critical appraisal}

All included studies were read and data were extracted by one reviewer. For data collection and assessment of risk of bias, a form was created based on the Data Extraction and Assessment Template by The Cochrane Public Health Group [6]. The obtained information included data on study design, population, intervention, methods, outcome and critical appraisal, among other things. As preferred outcome, mean of overall correct answers in a post-intervention comprehension test and respective statistical appraisal were obtained; if possible, absolute values where transformed to relative values. Furthermore, studies were clustered according to the intervention tested: enhanced paper forms, interspersed questions, multimedia format, and others. Levels of evidence are as follows: (1) randomized controlled trial (RCT); (2) controlled trial without randomization or prospective comparative cohort trial; (3) case-control study or retrospective cohort study; (4) case series with or without intervention or cross-sectional study or study without control [7]. In case of queries about the data collection and appraisal process, these were discussed with at least one of the other reviewers and a joint solution was found. 


\section{Results}

The primary search produced 7063 reports which were complemented by 26 reports obtained from other sources. After removal of duplicates and screening of titles and/or abstracts, 225 potentially relevant publications were identified and the full-texts were screened for eligibility. Application of exclusion criteria resulted in 19 studies with 2805 participants that were included in the analysis (Fig. 1).

\section{Study characteristics}

The nineteen included studies were conducted in seven different countries (Fig. 2) and comprised ten (53\%) RCTs of which six $(32 \%)$ failed to clearly state the method employed for group allocation. Assessors were stated to be blinded only in two studies (11\%). Overall, fourteen studies $(74 \%)$ compared an intervention to a control and thirteen (68\%) used a standard assent process/form as control. A large variety of methods were used to assess understanding ranging from written questionnaires with multiple choice or open-ended questions in most studies to interviews and observations. Two studies $(11 \%)$ included less than five participants. Assent processes in real research settings were covered by seven studies (37\%) while the others (63\%) used hypothetical or simulated study protocols. In total, six studies (32\%) reported their outcomes incompletely. (Table 1)

\section{Interventions}

Nine studies investigated the effects of using enhanced paper forms during the assent process. Enhanced forms included those with simplified text, illustrations, supplemental information, and narrative approaches. Six studies tested an enhanced assent form against the respective standard form as a control. Five of the six studies stated to use randomization for group allocation. Three of these studies found that the enhanced form resulted in significantly better understanding than the standard form, while one study found the opposite being the case $[9,17,21,23]$. However, the one study describing the standard form to be more effective was the only one where the intervention and the standard form did not cover the same content, but were used for two different clinical trials [9]. A non-randomized study found the enhanced form to significantly improve understanding in adolescent patients suffering substance use disorder but to have no effect in the control group of healthy adolescents [14]. Another randomized study tested block text format against questions and answers (Q\&A) as well as story format, but failed to provide statistical calculations for the means of correct answers. Instead, they only stated that the highest portion of participants that answered all questions correctly was in the story group [11]. Three additional studies found that using everyday language with graphs and Q\&A format, an illustrated booklet, and a comic strip in the assent process generally led to good understanding of the research details, but the interventions were not tested against a standard or control format $[16,18,20]$.

Three studies investigated the effects of using questions that assessed comprehension being interspersed during the assent process. All three studies compared the standard form with the same form plus probing questions during the process. Two studies used randomization for group allocation. Two studies found the understanding to be improved with interspersed questions during the assent process. However, one study considered the effect not to be significant with $p=0.055$ [12], while the other study used the same questions for probing during the process and assessment of understanding after the process [15]. The third study described better understanding of study purpose and benefits with probing questions but failed to provide the respective data and statistics in the report [8].
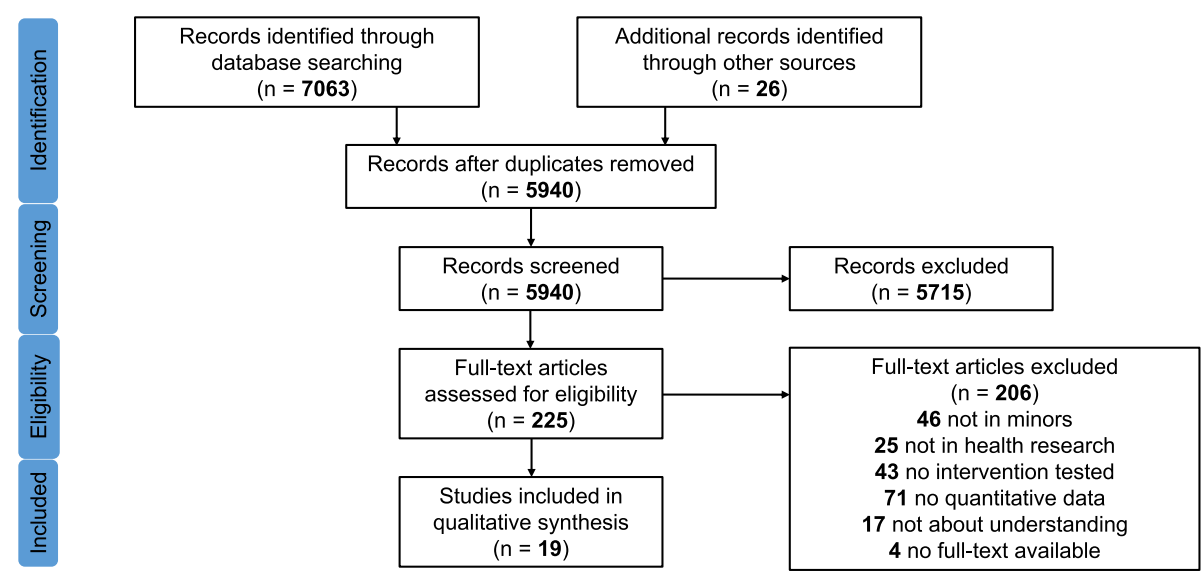

Fig. 1 PRISMA flow chart for study selection 


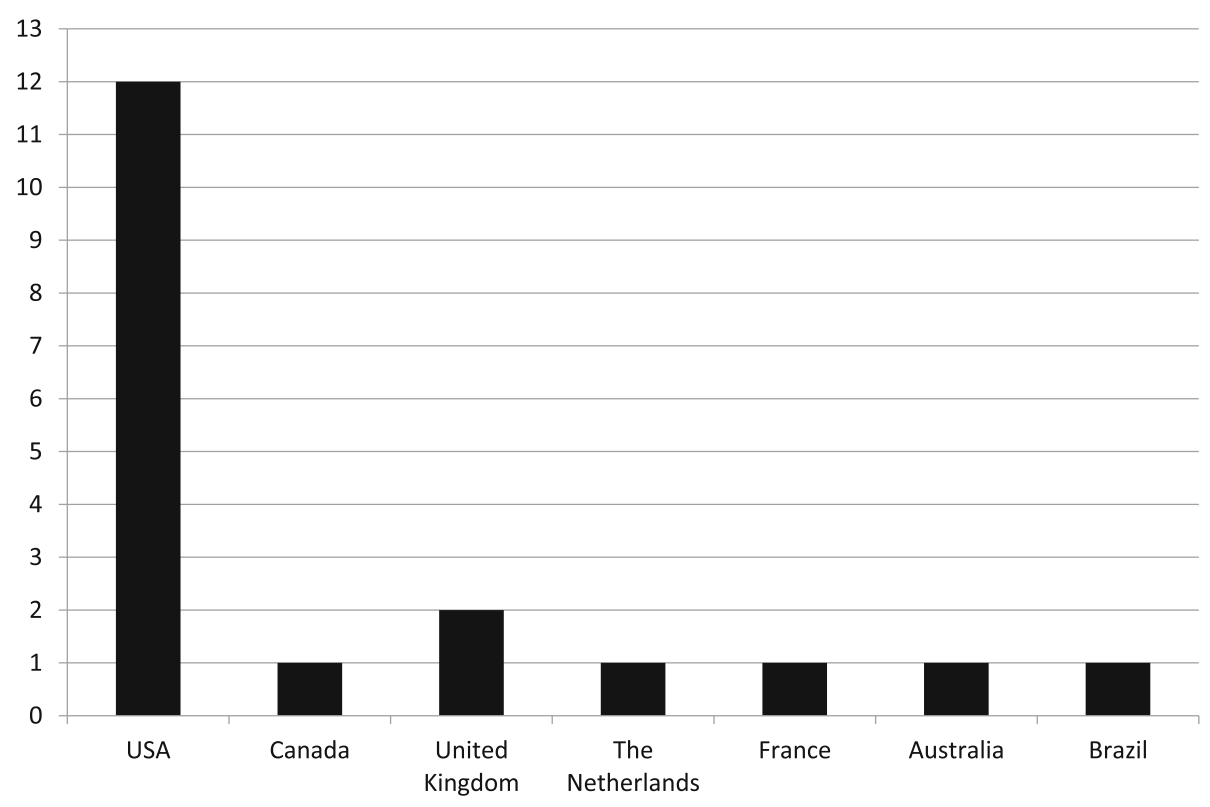

Fig. 2 Regional distribution of included studies

Five studies investigated the effects of using multimedia formats during the assent process. Three studies were RCTs that tested a multimedia format against the standard form. One study found the multimedia approach to significantly increase comprehension levels compared to the standard form, while another study found no significant difference [12, 22]. Another RCT tested a multimedia format with interactive, interspersed exercises against the standard form and found the multimedia format to be significantly better in improving understanding in the adolescent participants [25]. Two additional studies tested a non-fiction narrative on a touch computer and a dialogue by avatars in a low number of participants without a control condition [19, 24]. Interestingly, one study included two three-year-old children who could already be successfully introduced to certain aspects of research [19].

Three more studies investigated the effects of other interventions during the assent process. One RCT showed that adolescents above the age of 15 years demonstrated higher levels of comprehension when the assent process for them and their parents was conducted separately, while younger children showed no differences [10]. In a cross-sectional study, several different methods to explain probabilities were tested against each other, demonstrating that illustrations as pie charts were easiest to understand for children, followed by verbal labels, percentages, proportions as words, and proportions as notation [26]. An observational study demonstrated in interviews that understanding of study details was better if the recruitment and assent process took place more than seven days after the respective diagnosis. However, participants from several different clinical trials were included in the study and not controlled for their allocation which might have influenced the observed effect [13].

\section{Discussion}

This review includes nineteen studies of which twelve have not yet been covered by Grootens-Wiegers et al. in a former systematic review [5]. We made an effort to cover a broad spectrum by inclusion of many regional databases and the literature search was designed to particularly imbed literature from many different cultural backgrounds. Unfortunately, only one study from a lowand middle-income country met the inclusion criteria for this review, while all other included studies come from Organization for Economic Co-operation and Development (OECD) countries (Fig. 2).

In general, reliable data published on this subject was scarce. At study level, we identified several factors that limit the power of the presented results. These include the low number of RCTs and the failure to sufficiently report the group allocation processes. The nature of the assent process impeded blinding of group allocation, whereas the possible blinding of assessors was undertaken only in two trials. In five studies, interventions were not tested against control, at all. Additionally, many of the comprised studies featured incomplete outcome reporting. This included especially the failure to provide mean and standard deviation values as well as the lack of statistical analysis.

The format of a rapid systematic review was chosen to provide high-level evidence for health researchers that 
Table 1 Evidence for comprehension in informed assent processes.

\begin{tabular}{|c|c|c|}
\hline Authors & Study design & Intervention \& Control \\
\hline $\begin{array}{l}\text { Abramovitch } \\
\text { et al. (1995) } \\
\text { [8] }\end{array}$ & $\begin{array}{l}\text { Non-RCT } \\
\text { Participants: } 177 \text { healthy } \\
\text { children (7-12 years) } \\
\text { Description: } 3 \text { sub- } \\
\text { studies on memory, } \\
\text { hearing loss and } \\
\text { personality } \\
\text { Simulated scenario }\end{array}$ & $\begin{array}{l}\text { Control: Standard } \\
\text { descriptions of the sub- } \\
\text { studies ( } n=131 \text { ) } \\
\text { Intervention: Standard } \\
\text { descriptions + probing } \\
\text { questions after } \\
\text { descriptions of each study } \\
(n=46)\end{array}$ \\
\hline $\begin{array}{l}\text { Adcock et al. } \\
\text { (2012) [9] }\end{array}$ & $\begin{array}{l}\text { Crossover-RCT } \\
\text { Participants: } 217 \text { school } \\
\text { children (7-11 years) } \\
\text { Description: studies on } \\
\text { blood pressure and } \\
\text { gastroesophageal reflux } \\
\text { Simulated scenario }\end{array}$ & $\begin{array}{l}\text { Control: Standard assent } \\
\text { form with } 2 \text { pages in } \\
\text { paragraph form }(n=190) \\
\text { Intervention: KidSent } \\
\text { assent booklet with } 16 \\
\text { pages with sentences and } \\
\text { pictures ( } \mathrm{n}=195) \\
\text { First, participants read one } \\
\text { of the documents; } 3 \text { days } \\
\text { later, they read the other } \\
\text { document }\end{array}$ \\
\hline
\end{tabular}

Annett et al. RCT

(2017) [10] Participants: 64 healthy and ill adolescents (1217 years)

Description: clinical trial on asthma

Real scenario
Control: Standard assent process with adolescent and parent together $(n=$ 34)

Intervention: Separate assent process for adolescent and parent in different rooms $(n=34)$
Measurement:

Understanding of study purpose, risks, procedures, and right to withdraw Time point: immediately after reading the respective document

Outcome
Measurement:
Understanding of
purpose, good things, and
bad things
Time point: after the
description of all 3 studies

Measurement:
Understanding of study
purpose, risks, procedures,
and right to withdraw
Time point: immediately
after reading the
respective document

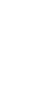

Measurement:

Understanding of asthma trial medicines, research process, rights and privileges, and risks and benefits

Time point: immediately after assent process
Barnett et al. RCT

(2005) [11] Participants: 374 school children (9-11 years, first language English)

Description: in 7 schools; study how to convey concept of RCTs Simulated scenario

\section{Blake et al. RCT}

(2015) [12] Participants: 120 adolescents (15-17 years, English-speaking, from youth serving agencies) Description: hypothetical HIV vaccine trial Simulated scenario
Control: Standard block text format $(n=123)$ Interventions: (1) Question and answer (Q\&A) format $(n=126)$ and (2) Story presentation $(n=124)$
Control: Standard paper assent $(n=31)$ Interventions: (1) Standard paper assent with interspersed questions $(n=29)$ and (2) Webbased assent with

interspersed questions, videos, and clip arts ( $n=$ 60)
Measurement: Understanding of randomization, safety and effectiveness, voluntariness, and avenue of redress

Time point: immediately after reading information

Measurement: Understanding of assent content

Time point: immediately after assent process
Findings

With probing questions,

children understood

purpose and good

things better than without interspersed

questions; no effect on understanding of bad things

Mean of correct answers

for standard form $\mathbf{7 8 . 5 \%}$

and for KidSent booklet

71.8\%; significant

difference between both

groups

Other results: more

children in KidSent

booklet group had perfect

scores $(34,7 \%)$ than in

standard form group (22,

1\%); most children stated that they understood the KidSent booklet better

In knowledge about risks and benefits, minors over 15 years scored better when assent was

separate

Younger children showed no difference

Other results: Parents of older minors also showed better understanding when assent was separate; 15-17-year-olds scored better in asthma medicine than 12-14-year-olds

Mean of correct answers

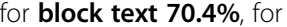
Q\&A 66.9\%, and for story $64.2 \%$

Other results: Significant difference for amount of participants that answered all questions per topic correct (story presentation scored best)

Mean of correct answers

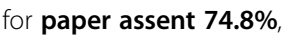
for paper assent with questions $\mathbf{8 1 . 8 \%}$, and for web-based assent $78.1 \%$; no significant differences

Other results: No

significant difference for amount of participants that answered at least 80\% correct (paper assent with questions best)

Mean of correct answers when trial recruitment took place more than 7 days after diagnosis $46 \%$ and when it took place earlier $\mathbf{2 0 . 8 \%}$;
Critical appraisal

Quality Rating: 2

Incomplete outcome reporting

Non-comparable data provided Recruitment methods and selection unclear

Quality Rating: 1

2 different studies were covered by the control and intervention form; one might have been more difficult to understand Randomization methods partly unclear

Quality Rating: 1 Incomplete outcome reporting Values for understanding between intervention and control not provided No description of randomization process

Quality Rating: 1 No statistics provided for comparison of mean scores No description of randomization process

Quality Rating: 1 Less interaction with researcher in web-

based assent Randomization methods stated

Quality Rating: 3 No controlled groups Inclusion of several different clinical trials may have influenced outcomes direct and indirect

benefits, right to
Measurement:

Understanding of study purpose, protocol design 8,5-18 years) recently recruited for understanding of study

processes 
Table 1 Evidence for comprehension in informed assent processes. (Continued)

\begin{tabular}{|c|c|c|c|c|c|}
\hline Authors & Study design & Intervention \& Control & Outcome & Findings & Critical appraisal \\
\hline & $\begin{array}{l}\text { other clinical trials } \\
\text { Real scenario }\end{array}$ & & $\begin{array}{l}\text { withdraw, duration, } \\
\text { alternatives, voluntariness } \\
\text { Time point: after } \\
\text { recruitment for respective } \\
\text { clinical trial }\end{array}$ & $\begin{array}{l}\text { significant difference } \\
\text { between both groups } \\
\text { Other results: adolescents } \\
\text { older than } 14 \text { years scored } \\
\text { better than younger ones }\end{array}$ & $\begin{array}{l}\text { Small sample, } \\
\text { potential bias by } \\
\text { group imbalances }\end{array}$ \\
\hline $\begin{array}{l}\text { Coors et al. } \\
\text { (2016) [14] }\end{array}$ & $\begin{array}{l}\text { Non-RCT } \\
\text { Participants: } 76 \text { healthy } \\
\text { and ill adolescents } \\
\text { (substance use disorder, } \\
\text { 14-17 years, no intellec- } \\
\text { tual deficiency) } \\
\text { Description: biobanking } \\
\text { and genomics study in }\end{array}$ & $\begin{array}{l}\text { Control: Standard risk } \\
\text { information } \\
\text { Intervention: Standard risk } \\
\text { information + additional } \\
\text { information on } 7 \\
\text { previously identified } \\
\text { salient risks }\end{array}$ & $\begin{array}{l}\text { Measurement: } \\
\text { Understanding of risks } \\
\text { Time point: immediately } \\
\text { after assent process }\end{array}$ & $\begin{array}{l}\text { In patients, the } \\
\text { additional information } \\
\text { on salient risks improved } \\
\text { scores significantly } \\
\text { In healthy adolescents, } \\
\text { there was no significant } \\
\text { difference }\end{array}$ & $\begin{array}{l}\text { Quality Rating: } 2 \\
\text { Incomplete outcome } \\
\text { reporting } \\
\text { No description of } \\
\text { allocation of } \\
\text { participants; numbers } \\
\text { per group unclear }\end{array}$ \\
\hline
\end{tabular}

Friedman $\quad \mathrm{RCT}$

et al. (2016) Participants: 568 healthy

[15]

adolescents (14-17

nomics study in

several stages

Real scenario

years, male only, gay or bisexual)

Description: survey on

online behaviour of gay

youth

Real scenario

Control: Study information

$(n=186)$

Interventions: (1) Study

information +

requirement to answer 2 after survey

questions correctly $(n=$

187) and (2) Study

information +

requirement to answer 7

questions correctly ( $n=$

195)

Intervention: Comic strip Measurement:

Wiegers et al. Participants: 101 school

(2015) $[5,16]$ children (10-13 years)

Description: comic

about characteristics of

research studies

Simulated scenario

Lally et al. $\quad$ RCT

(2014) [17] Participants: 120 adolescents (16-19 years old, male/female who have sex with men) Description: consent and brochures on characteristics of an HIV vaccine trial Simulated scenario

Lee et al.

Interventional study

(2013) [18] Participants: 123

adolescents (12-17

years)

Description: study on

Hepatitis B vaccination

in youth

Real scenario

Mayne et al. Case series with

(2017) [19] intervention

Participants: 2 children

(3 years)

Description: Story of a

toymaker who makes

science toys

with information on

medical research $(n=101)$

Understanding of 8

research aspects

Time point: after reading

the comic strip

Control: Standard

informed consent $(n=42)$

Interventions: (1) Informed

consent with 1-sided

supplemental informa-

tion (presentation of

pertinent facts) $(n=39)$ and

(2) Informed consent with

2-sided supplemental in-

formation $(n=39)$

(presentation of common misconceptions and rebuttal with factual information)

Intervention: Simplified assent form with every day, non-medical language and supporting graphs in a Q\&A format

Intervention: Interactive nonfiction narrative (powerpoint with photos, clip arts, active buttons) on touch computer; concepts: dialogic reading, Time points: 1 week
sustained shared thinking, before, 2 and 9 weeks

Measurement: Understanding of randomization, interpretation of side effects, and unproven efficacy (part of consent and intervention of non-brochure topics Time point: immediately after reading the information

Measurement: Understanding of future benefits, blinding, direct benefit, voluntariness Time point: immediately after reading the form

Measurement: purpose and context, participatory rights, and participator easurement:

Understanding of risks

and voluntariness

Time point: immediately

Mean of correct answers

for information without questions $63 \%$, with 2

questions $92.5 \%$, and

with 7 questions $93 \%$;

significant difference

between conditions with

and without questions

Other results: assent

significantly rarer

completed when

questions interspersed

Quality Rating: 1

Questions to assess understanding at the end are the same as used in the intervention Online study with high number of dropouts

Male participants only

Randomization methods stated

Mean of correct answers Quality Rating: 4 for comic strip 83.0\%; $\quad$ No control group best score for side effects, Recruitment methods worst score for anonymity and selection unclear Other results: survey on Dropouts not user satisfaction described

brochures); understanding procedure, randomization Understanding of research

Mean of correct answers Quality Rating: 1

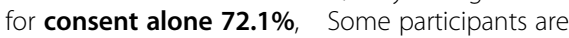
for consent $+\mathbf{1}$-sided in- older than 18 years formation $\mathbf{7 8 . 6 \%}$, and for Randomization consent + 2-sided infor- methods stated mation $80.2 \%$; significant difference between consent only and consent +2 -sided information for randomization and side effects Other results: no significant differences for topics not covered by the supplemental brochures

Mean of correct answers for the simplified assent form $\mathbf{8 5 . 8 \%}$

Other results: $56.1 \%$ answered all questions correctly 5-point Likert-type response scale potentially inappropriate for understanding items

Quality Rating: 4 No control group Dropouts not described

Understanding of the

Quality Rating: 4 basic research concepts No control group improved or stayed high Only 2 selected after presentation of the participants interactive narrative Incomplete outcome data due to erratic interest of 
Table 1 Evidence for comprehension in informed assent processes. (Continued)

\begin{tabular}{|c|c|c|c|c|c|}
\hline Authors & Study design & Intervention \& Control & Outcome & Findings & Critical appraisal \\
\hline & Simulated scenario & cycle telling and retelling & after outreach & & participants \\
\hline $\begin{array}{l}\text { Miranda } \\
\text { et al. (2017) } \\
\text { [20] }\end{array}$ & $\begin{array}{l}\text { Interventional study } \\
\text { Participants: } 42 \\
\text { hospitalized children (5- } \\
10 \text { years, clinically } \\
\text { stable) } \\
\text { Description: study on } \\
\text { vulnerability during } \\
\text { illness and } \\
\text { hospitalization } \\
\text { Real scenario }\end{array}$ & $\begin{array}{l}\text { Intervention: Illustrated } \\
\text { booklet (text, images, } \\
\text { illustrations for colouring) }\end{array}$ & $\begin{array}{l}\text { Measurement: } \\
\text { Understanding of research } \\
\text { proposal } \\
\text { Time point: during } \\
\text { application of booklet }\end{array}$ & $\begin{array}{l}\text { All children understood } \\
\text { the research proposal } \\
\text { Other results: Children } \\
\text { wanted the booklet to be } \\
\text { able to colour it }\end{array}$ & $\begin{array}{l}\text { Quality Rating: } 4 \\
\text { No control group } \\
\text { Understanding was } \\
\text { assessed only by } \\
\text { "observations by } \\
\text { researcher" } \\
\text { Inconclusive outcome } \\
\text { reporting }\end{array}$ \\
\hline $\begin{array}{l}\text { Murphy et al. } \\
\text { (2007) [21] }\end{array}$ & $\begin{array}{l}\text { RCT } \\
\text { Participants: } 187 \text { healthy } \\
\text { adolescents (15-19 } \\
\text { years, male/female/ } \\
\text { transgender, at risk for } \\
\text { HIV, English-speaking) } \\
\text { Description: study on } \\
\text { HIV vaccination } \\
\text { Simulated scenario }\end{array}$ & $\begin{array}{l}\text { Control: HIVNET standard } \\
\text { assent form ( } n=94) \\
\text { Intervention: Based on } \\
\text { HIVNET version, but } \\
\text { reorganized, simplified } \\
\text { text, implementation of } \\
\text { illustrations }(n=93)\end{array}$ & $\begin{array}{l}\text { Measurement: } \\
\text { Understanding of study } \\
\text { details including } \\
\text { procedures, benefits and } \\
\text { risks } \\
\text { Time point: immediately } \\
\text { after assent process }\end{array}$ & $\begin{array}{l}\text { Mean of correct answers } \\
\text { for standard version } \\
\mathbf{7 1 . 7 \%} \text { and for illustrative } \\
\text { version with simplified } \\
\text { text } \mathbf{8 0 . 5 \%} \text {; significant } \\
\text { difference between both } \\
\text { groups } \\
\text { Other results: } \\
\text { understanding of } \\
\text { procedures and benefits } \\
\text { was also significantly } \\
\text { better in the intervention } \\
\text { group; illustrative version } \\
\text { with simplified text } \\
\text { contained fewer words, } \\
\text { fewer words per sentence, } \\
\text { less passive voice, and had } \\
\text { higher reading ease }\end{array}$ & $\begin{array}{l}\text { Quality Rating: } 1 \\
\text { No description of } \\
\text { randomization } \\
\text { process } \\
\text { No indication of } \\
\text { standard deviations } \\
\text { Simplified text and } \\
\text { illustrations are tested } \\
\text { together } \\
\text { Some participants are } \\
\text { older than } 18 \text { years }\end{array}$ \\
\hline $\begin{array}{l}\text { O'Lonergan } \\
\text { and Forster- } \\
\text { Harwood } \\
(2011) \text { [22] }\end{array}$ & $\begin{array}{l}\text { RCT } \\
\text { Participants: } 170 \\
\text { children (11-14 years, no } \\
\text { deficits in cognition, } \\
\text { hearing, or vision, did } \\
\text { not undergo procedures } \\
\text { yet) together with } \\
\text { parents } \\
\text { Description: study } \\
\text { involving common } \\
\text { procedures in } \\
\text { paediatrics (DXA and } \\
\text { abdominal ultrasound) } \\
\text { Simulated scenario }\end{array}$ & $\begin{array}{l}\text { Control: Standard } \\
\text { permission and assent } \\
\text { process ( } n=87 \text { ) } \\
\text { Intervention: Multimedia } \\
\text { process in Microsoft } \\
\text { PowerPoint with same } \\
\text { text like standard process } \\
\text { but with hyperlinks to } \\
\text { videos and voice-overs } \\
(n=83)\end{array}$ & $\begin{array}{l}\text { Measurement: } \\
\text { Understanding of essential } \\
\text { elements of the } \\
\text { permission and assent } \\
\text { process } \\
\text { Time point: immediately } \\
\text { after assent process }\end{array}$ & $\begin{array}{l}\text { Mean of points for correct } \\
\text { answers for standard } \\
\text { process } \mathbf{4 4 \%} \text { and for } \\
\text { multimedia process } \\
\mathbf{5 1 . 2 \%} \text {; significant } \\
\text { difference between both } \\
\text { groups for total score, } \\
\text { study procedures, and } \\
\text { risks } \\
\text { Other results: parents also } \\
\text { scored significantly better } \\
\text { with multimedia process; } \\
\text { all participants } \\
\text { overestimated their } \\
\text { comprehension }\end{array}$ & $\begin{array}{l}\text { Quality Rating: } 1 \\
\text { No description of } \\
\text { randomization } \\
\text { process } \\
\text { Incomplete outcome } \\
\text { reporting (answers to } \\
\text { some questions were } \\
\text { not presented } \\
\text { individually) }\end{array}$ \\
\hline $\begin{array}{l}\text { Tait et al. } \\
\text { (2007) [23] }\end{array}$ & $\begin{array}{l}\text { RCT } \\
\text { Participants: } 190 \\
\text { hospitalized children (7- } \\
17 \text { years, no cognitive } \\
\text { impairment, no } \\
\text { emergent illness) } \\
\text { Description: study on } \\
\text { postoperative nausea } \\
\text { and vomiting } \\
\text { Simulated scenario }\end{array}$ & $\begin{array}{l}\text { Control: Standard form } \\
\text { including verbal } \\
\text { explanation ( } \mathrm{n}=95) \\
\text { Intervention: Modified } \\
\text { form with improved } \\
\text { readability and } \\
\text { processability as well as } \\
\text { use of bullets, bolding, } \\
\text { increased font size, and } \\
\text { pictures (also including } \\
\text { verbal explanation) ( } \mathrm{n}=95)\end{array}$ & $\begin{array}{l}\text { Measurement: } \\
\text { Understanding of purpose } \\
\text { of study, protocol, risks, } \\
\text { direct and indirect } \\
\text { benefits, alternatives, } \\
\text { voluntariness, and } \\
\text { freedom to withdraw } \\
\text { Time point: immediately } \\
\text { after assent process }\end{array}$ & $\begin{array}{l}\text { Mean of points for correct } \\
\text { answers for standard } \\
\text { form } 60.4 \% \text { and for } \\
\text { modified form } 68.5 \% \text {; } \\
\text { significant difference } \\
\text { between both groups } \\
\text { Other results: differences } \\
\text { between groups were } \\
\text { higher in younger } \\
\text { children; most children } \\
\text { preferred modified form; } \\
\text { all children overestimated } \\
\text { their comprehension }\end{array}$ & $\begin{array}{l}\text { Quality Rating: } 1 \\
\text { No description of } \\
\text { randomization } \\
\text { process } \\
\text { Large number } \\
\text { declined } \\
\text { participation; possibly } \\
\text { selection bias of } \\
\text { highly motivated } \\
\text { children } \\
\text { Assessors were } \\
\text { blinded }\end{array}$ \\
\hline $\begin{array}{l}\text { Tait et al. } \\
\text { (2012) [24] }\end{array}$ & $\begin{array}{l}\text { Before and after study } \\
\text { Participants: } 4 \text { children } \\
\text { (8-14 years, from } \\
\text { waiting room in } \\
\text { hospital) } \\
\text { Description: pilot study; } \\
\text { trial on asthma } \\
\text { Simulated scenario }\end{array}$ & $\begin{array}{l}\text { Intervention: 3D } \\
\text { modelled avatars } \\
\text { present a dialogue } \\
\text { between a child and a } \\
\text { doctor in an interactive } \\
\text { program }\end{array}$ & $\begin{array}{l}\text { Measurement: Pre- and } \\
\text { post-intervention under- } \\
\text { standing of clinical trial, } \\
\text { randomization, placebo, } \\
\text { and blinded study; post- } \\
\text { intervention understand- } \\
\text { ing of elements of the } \\
\text { study }\end{array}$ & $\begin{array}{l}\text { Correct descriptions of the } \\
4 \text { terms from pre- to post- } \\
\text { intervention: } \mathbf{2 5 \%} \text { to } \mathbf{5 0 \%} \% \\
\mathbf{0} \% \text { to } 0 \%, \mathbf{0} \% \text { to } \mathbf{5 0} \% \text {, } \\
\text { and } \mathbf{2 5 \%} \text { to } 50 \% \text {; mean } \\
\text { of points for correct an- } \\
\text { swers about elements of } \\
\text { the study } 61.7 \%\end{array}$ & $\begin{array}{l}\text { Quality Rating: } 4 \\
\text { No control group } \\
\text { Only } 4 \text { participants }\end{array}$ \\
\hline
\end{tabular}


Table 1 Evidence for comprehension in informed assent processes. (Continued)

\begin{tabular}{|c|c|c|c|c|c|}
\hline Authors & Study design & Intervention \& Control & Outcome & Findings & Critical appraisal \\
\hline & & & $\begin{array}{l}\text { Time point: directly before } \\
\text { and after using the } \\
\text { program }\end{array}$ & & \\
\hline $\begin{array}{l}\text { Tait et al. } \\
\text { (2015) [25] }\end{array}$ & $\begin{array}{l}\text { RCT } \\
\text { Participants: } 135 \\
\text { children (10-17 years, } \\
\text { attendants of a } \\
\text { paediatric clinic, no } \\
\text { cognitive impairments, } \\
\text { English-speaking) } \\
\text { Description: study on } \\
\text { general aspects of trials } \\
\text { Simulated scenario }\end{array}$ & $\begin{array}{l}\text { Control: Standard paper } \\
\text { form (text only) ( } n=68) \\
\text { Intervention: Interactive } \\
\text { iPad program in written } \\
\text { and visual formats } \\
\text { together with voice-over } \\
\text { and interactive exercises } \\
\text { with corrective feedback } \\
\text { (content identical to } \\
\text { standard form) }(n=67)\end{array}$ & $\begin{array}{l}\text { Measurement: } \\
\text { Understanding of clinical } \\
\text { trial, participation, } \\
\text { protocol, randomization, } \\
\text { placebo, blinding, double- } \\
\text { blinding, effectiveness, } \\
\text { and informed consent } \\
\text { Time point: immediately } \\
\text { after reading the } \\
\text { information }\end{array}$ & $\begin{array}{l}\text { Mean of points for correct } \\
\text { answers for standard } \\
\text { form } 49.2 \% \text { and for } \\
\text { interactive program } \\
64.7 \% \text {; significant } \\
\text { difference between both } \\
\text { groups } \\
\text { Other results: most } \\
\text { children preferred the } \\
\text { interactive program over } \\
\text { the standard form }\end{array}$ & $\begin{array}{l}\text { Quality Rating: } 1 \\
\text { Randomization } \\
\text { methods stated } \\
\text { Assessors were } \\
\text { blinded }\end{array}$ \\
\hline $\begin{array}{l}\text { Ulph et al. } \\
\text { (2009) [26] }\end{array}$ & $\begin{array}{l}\text { Cross-sectional study } \\
\text { Participants: } 106 \text { school } \\
\text { children (7-11 years) } \\
\text { Description: study on } \\
\text { methods to convey } \\
\text { probabilities in a cup } \\
\text { game } \\
\text { Simulated scenario }\end{array}$ & $\begin{array}{l}6 \text { different formats were } \\
\text { tested in all participants: } \\
\text { (1) verbal labels (rare) } \\
\text { (2) percentages (1\%) } \\
\text { (3) pie charts } \\
\text { (4) proportions as words } \\
\text { (1 in } 100) \\
\text { (5) proportions as } \\
\text { notation }(1: 100) \\
\text { (6) mixed format }\end{array}$ & $\begin{array}{l}\text { Measurement: } 3 \text { trials to } \\
\text { choose the highest } \\
\text { probability shown for } \\
\text { each format } \\
\text { Time point: during the } \\
\text { game }\end{array}$ & $\begin{array}{l}\text { Mean of points for correct } \\
\text { answers was highest for } \\
\text { pie charts }(90 \%), \text { followed } \\
\text { by verbal labels, } \\
\text { percentages ( } 79 \%) \text {, } \\
\text { proportions as words } \\
(64 \%), \text { proportions as } \\
\text { notation }(62.7 \%) \text {, and } \\
\text { mixed format }(43 \%)\end{array}$ & $\begin{array}{l}\text { Quality Rating: } 4 \\
\text { Game may not } \\
\text { represent complexity } \\
\text { of medical research } \\
\text { Only understanding } \\
\text { of probability was } \\
\text { tested } \\
\text { Incomplete outcome } \\
\text { reporting }\end{array}$ \\
\hline
\end{tabular}

work with minors in a timely manner. This decision comes with limitations at review-level: only one author conducted the principal literature search and data collection. This may have resulted in incomplete retrieval of identified research. However, we made an additional effort to improve the quality of this review by inclusion of at least one other reviewer in any case of doubts during the process of literature screening, data collection, and critical appraisal. Unfortunately, the limitations at study-level impeded additional (meta-)analyses of the presented interventions.

To differentiate individual opinions and views from verifiable results, we decided to exclude qualitative studies from this review. Nevertheless, new ways to communicate information in research have been tested in qualitative studies, as well. Dockett et al. report how one child emphasized the importance of illustrations in information forms: 'I just read the pictures.' [27] Another report described the process of involving children in the development of information and assent forms. The children exclusively used active voice and named all function owners [28]. However, their effects on comprehension still needs to be assessed.

\section{Conclusions}

This report on a rapid systematic review includes nineteen studies that investigated factors in research assent processes in order to improve comprehension in underage participants. Unfortunately, available data on this topic proved to be rare and several major limitations restrict the power of the findings, so that we did not attain our initial goal to be able to provide researchers explicit evidence-based recommendations.

Nevertheless, positive impact on children's and adolescents' comprehension of research information was suggested for enhanced paper forms (e.g. by simplified text or illustrations), for the use of interspersed questions, for assent processes that are conducted separately from parents for adolescents older than 15 years, for the use of pie charts to communicate probabilities, and if trial recruitment took place more than seven days after diagnosis. The positive effect of simplified language, illustrations, and narrative approaches in enhanced paper forms may not be surprising given that presentations using various visualizations are generally supposed to be easier to understand and to follow [29]. And just like repetition is a widely accepted tool to study and understand any topic, the shown benefit from interspersed questions that require participants to double-check their own comprehension is quite intuitive. Like the use of pie charts, whenever probabilities are meant to be conveyed, both techniques are easily included in any kind of information sheets.

Younger children might profit from elements that show no impact in older ones and vice versa. Adolescents might feel a greater responsibility for their decisions. In line with that, Hein et al. claimed that children from the age of twelve may already be capable of giving consent instead of assent [30]. Therefore, future research on this topic should consider testing different interventions in different age groups. 
On the whole, the area of assent remains a largely under-researched issue. Further research and standardization of measures still remain necessary to be able to give stronger evidence-based recommendations.

\section{Supplementary information}

Supplementary information accompanies this paper at https://doi.org/10. 1186/s12874-020-01000-3.

Additional file 1 Table S1. Search strategies.

Additional file 2. PRISMA checklist.

\section{Abbreviations}

Q\&A: Questions and answers; RCT: Randomized controlled trial; OECD: Organization for Economic Co-operation and Development; CIOMS: Council for International Organizations of Medical Sciences; PRISMA: Preferred Reporting Items for Systematic Reviews and Meta-Analyses

\section{Acknowledgments}

Maria Magdalena Guraiib, Dr Andreas Alois Reis, and Dr Nigel Campbell Rollins are staff members of the World Health Organization. The views expressed in this article do not necessarily represent the views of the World Health Organization, but are in the authors' responsibility.

We gratefully acknowledge Mr Thomas Allen, the WHO librarian, for his advice on the search strategies.

\section{Authors' contributions}

DS screened titles and abstracts, assessed the full-text articles, extracted and analyzed the data and wrote the manuscript. MMG and AAR conceived the study and supervised the work. NCR substantively revised the work. All authors approved the final manuscript.

\section{Funding}

Dominik Soll is grateful for a scholarship from the German Academic Exchange Service (DAAD) during his internship in the WHO Global Health Ethics Unit.

\section{Availability of data and materials}

The datasets used and analyzed during the current study are available from the corresponding author on request.

\section{Ethics approval and consent to participate}

Not applicable.

\section{Consent for publication}

Not applicable.

\section{Competing interests}

The authors have no conflicts of interest to declare for this study.

\section{Author details}

'Department of Endocrinology and Metabolism, Charité Universitätsmedizin Berlin, Berlin, Germany. ${ }^{2}$ Global Health Ethics Team, World Health Organization, Geneva, Switzerland. ${ }^{3}$ Maternal, Newborn, Child and Adolescent Health, World Health Organization, Geneva, Switzerland.

Received: 24 September 2019 Accepted: 30 April 2020 Published online: 13 May 2020

\section{References}

1. U.S. National Library of Medicine. ClinicalTrials.gov. Available from: https:// clinicaltrials.gov/. Accessed 5 Mar 2020.

2. Council for International Organizations of Medical Sciences. International Ethical Guidelines for Health-related Research Involving Humans. Available from: https://cioms.ch/wp-content/uploads/2017/01/WEB-CIOMSEthicalGuidelines.pdf. Accessed 1 Jul 2019.
3. Unguru Y, Sill AM, Kamani N. The experiences of children enrolled in pediatric oncology research: implications for assent. Pediatrics. 2010;125(4): e876-83.

4. Twycross A, Gibson F, Coad J. Guidance on seeking agreement to participate in research from young children. Paediatr Nurs. 2008;20(6):14-8.

5. Grootens-Wiegers $P$, de Vries MC, van den Broek JM. Research information for minors: Suitable formats and readability. A systematic review. J Paediatr Child Health. 2015:51(5):505-11.

6. Cochrane Public Health. Data Extraction and Assessment Template. Available from: https://ph.cochrane.org/review-authors. Accessed 1 Jul 2019.

7. JAMA Pediatrics. Quality Rating Scheme for Studies and Other Evidence. Available from: https://jamanetwork.com/journals/jamapediatrics/pages/ instructions-for-authors\#SecReviews. Accessed 1 Jul 2019.

8. Abramovitch R, Freedman JL, Henry K, VanBrunschot M. Children's capacity to agree to psychological research: Knowledge of risks and benefits and voluntariness. Ethics Behav. 1995;5(1):25-48

9. Adcock KG, Hogan SM, Elci OU, Mills KL. Do Illustrations Improve Children's Comprehension of Assent Documents? J Pediatr Pharmacol Ther. 2012;17(3):228-35.

10. Annett RD, Brody JL, Scherer DG, Turner CW, Dalen J, Raissy H. A randomized study of a method for optimizing adolescent assent to biomedical research. AJOB Empir Bioethics. 2017:8(3):189-97.

11. Barnett K, Harrison C, Newman F, Bentley C, Cummins C. A randomised study of the impact of different styles of patient information leaflets for randomised controlled trials on children's understanding. Arch Dis Childhood. 2005;90(4):364-6.

12. Blake DR, Lemay CA, Maranda LS, Fortenberry JD, Kearney MH, Mazor KM. Development and evaluation of a web-based assent for adolescents considering an HIV vaccine trial. AIDS care. 2015;27(8):1005-13.

13. Chappuy H, Doz F, Blanche S, Gentet JC, Treluyer JM. Children's views on their involvement in clinical research. Pediatr Blood Cancer. 2008:50(5):1043-6.

14. Coors ME, Raymond KM, Hopfer CJ, Sakai J, McWilliams SK, Young S, et al. Adolescents with substance use disorder and assent/consent: Empirical data on understanding biobank risks in genomic research. Drug Alcohol depend. 2016:159:267-71.

15. Friedman MS, Chiu CCJ, Croft C, Guadamuz TE, Stall R, Marshal MP. Ethics of Online Assent: Comparing Strategies to Ensure Informed Assent Among Youth. J Empir Res Hum Res Ethics. 2016;11(1):15-20.

16. Grootens-Wiegers $P$, de Vries MC, van Beusekom MM, van Dijck $L$, van den Broek JM. Comic strips help children understand medical research: targeting the informed consent procedure to children's needs. Patient Educ Couns. 2015:98(4):518-24.

17. Lally M, Goldsworthy R, Sarr M, Kahn J, Brown L, Peralta L, et al. Evaluation of an intervention among adolescents to reduce preventive misconception in HIV vaccine clinical trials. J Adolesc Health. 2014;55(2):254-9.

18. Lee S, Kapogiannis BG, Flynn PM, Rudy BJ, Bethel J, Ahmad S, et al. Comprehension of a simplified assent form in a vaccine trial for adolescents. J Med Ethics. 2013:39(6):410-2

19. Mayne F, Howitt C, Rennie LJ. Using interactive nonfiction narrative to enhance competence in the informed consent process with 3-year- old children. Int J Inclusive Educ. 2017;21(3):299-315

20. Miranda JdOF, Santos DVd, Camargo CLd, Nascimento Sobrinho CL, Rosa DdOS, Souza GMdS. ConstruÃßÃ£o e aplicaÃß̃̃£o de um termo de assentimento: relato de experiÃancia. Texto \& contexto enferm. 2017:26(3): e2460016-e

21. Murphy DA, Hoffman D, Seage GR, Belzer M, Xu J, Durak SJ, et al. Improving comprehension for HIV vaccine trial information among adolescents at risk of HIV. Aids Care. 2007:19(1):42-51.

22. O'Lonergan TA, Forster-Harwood JE. Novel Approach to Parental Permission and Child Assent for Research: Improving Comprehension. Pediatrics. 2011; 127(5):917-24.

23. Tait AR, Voepel-Lewis T, Malviya S. Presenting research information to children: A tale of two methods. Anesth Analg. 2007:105(2):358-64.

24. Tait AR, Voepel-Lewis T, McGonegal M, Levine R. Evaluation of a prototype interactive consent program for pediatric clinical trials: a pilot study. J Am Med Informatics Assoc. 2012;19(E1):E43-E5.

25. Tait AR, Voepel-Lewis T, Levine R. Using digital multimedia to improve parents' and children's understanding of clinical trials. Arch Dis Childhood. 2015:100(6):589-93.

26. Ulph F, Townsend E, Glazebrook C. How should risk be communicated to children: a cross-sectional study comparing different formats of probability information. BMC Med Informatics Decis Making. 2009;9:Article 26. https:// 
bmcmedinformdecismak.biomedcentral.com/articles/10.1186/1472-69479-26\#citeas.

27. Dockett S, Perry B, Kearney E. Promoting children's informed assent in research participation. Int J Qual Stud Educ. 2013;26(7):802-28.

28. Ford K, Sankey J, Crisp J. Development of children's assent documents using a child-centred approach. J Child Health Care. 2007;11(1):19-28.

29. Zerwic J, Grandfield K, Kavanaugh K, Berger B, Graham L, Mershon M. Tips for better visual elements in posters and podium presentations. Educ Health (Abingdon). 2010;23(2):267

30. Hein IM, De Vries MC, Troost PW, Meynen G, Van Goudoever JB, Lindauer $\mathrm{RJ}$. Informed consent instead of assent is appropriate in children from the age of twelve: Policy implications of new findings on children's competence to consent to clinical research. BMC Med Ethics. 2015;16(1):76.

\section{Publisher's Note}

Springer Nature remains neutral with regard to jurisdictional claims in published maps and institutional affiliations.

Ready to submit your research? Choose BMC and benefit from:

- fast, convenient online submission

- thorough peer review by experienced researchers in your field

- rapid publication on acceptance

- support for research data, including large and complex data types

- gold Open Access which fosters wider collaboration and increased citations

- maximum visibility for your research: over $100 \mathrm{M}$ website views per year

At BMC, research is always in progress.

Learn more biomedcentral.com/submissions 